\title{
TRIPLE-BOTTOM-LINE IMPACT ANALYSIS FRAMEWORK OF FINTECH COMPANIES
}

Financial institutions play a crucial role in the market economy. Banks act as intermediaries between savers and borrowers, decreasing information asymmetry and enabling investment. They play a crucial part in society by offering financial services to people and enabling corporate investment. Traditional bricks-and-mortar banks cannot sufficiently financially include all people - they particularly fail to reach the Bottom-of-the-Pyramid (BoP). Newly emerging financial technology companies - fintechs - have already started to fill the gap by providing services to the BoP, enabled by information and communications technology (ICT) and new business models. The triple-bottom-line (TBL) impact analysis of fintechs is a new, emerging research area. This article fills the gap in current literature by providing a proposed analytical framework with which to assess fintechs from a TBL-value-creation perspective. The article presents the benefits of the TBL Impact Analysis Framework of Fintechs based on findings from more than hundred currently operating fintechs and existing sustainable banking initiatives. The framework contains the direct and indirect TBL value creation elements of fintechs organized along their economic, social and environmental impact and can be used as a simple, yet effective assessment tool for analyzing the TBL impact of fintechs, helping to make TBL-related adjustments, improving upon currently offered solutions, or aiding in the design of financial new products with TBL value-creation elements.

Keywords: business models (BM), bottom of the pyramid (BoP), fintech, financial inclusion, sustainable banking, TBL impact analysis framework, triple-bottom-line (TBL)

$\mathrm{T}^{\mathrm{n}}$ he Club of Rome published a warning almost 50 years ago in the Limits to Growth (1971) that economic growth would not necessarily result in an increase in the well-being and wealth of individuals. The term sustainable development (SD) was formalized in 1987 to describe the need for a more complex solution to balancing economic growth and environmental, ecological and social improvements (Hall - Daneke - Lenox, 2010; Charter et al., 2008). This was in response to the realization that the economic structure and distribution of wealth is not sustainable (van der Bergh, 2007). SD must include inter-organizational networks and societal systems (Lélé, 1991) in which cultural expectations and customer demand play an important role in incentivizing organizations to change their current way of doing business (Birkin et al., 2009). Sustainable development at the company level must rely on a combination of strategy making and daily activities to meet stakeholders' expectations, while protecting, sustaining and enhancing social and natural resources (IISD, 1992). Recognition of the need for this symbiosis between economic, political, social and other elements of a functioning ecosystem has been known about at least since 1934 (Schumpeter, 1934). The role of companies in SD is unquestionable. The UN 2030 Agenda for Sustainable Development highlights the need for the creation of an efficient and sustainable economy as a major focal point (Mika - Farkas, 2017): clearly an area where corporations need to engage.

Elkington (1997) frames corporate sustainability using the concept of the Triple-Bottom-Line, according to which a company's strategy relies on three pillars: economic, environmental, and social value creation. Sustainable organizations understand that they have obligations toward their internal and external stakeholders, the people and planet when striving to make an economic profit. However, corporate sustainability has become a fashionable term, and companies often use SD rhetoric to improve their public image (Henderson, 2015). C-level executives are still having a hard time capturing the real benefits of triple-bottom-line perspectives. Research with 1.100 CEOs found no meaningful correlation between profit making and a positive return on social and environmental investment (Hansen et al., 2013).

Corporate sustainability requires systemic innovation (Boons et al., 2013) that goes beyond regular product and business development. Companies need to engage in a trial-and-error approach, versus the stage-gate trends of the 1980s and 1990s (Cooper, 1994). To be able to make such systemic change, different dimensions of society should be involved: markets systems, public policy and industrial norms, the relationship between the public and private sectors, integrating people at the BoP, and improving entrepreneurship (Fisac Garcia et al., 2013; Ashoka, 2010). Stakeholder relationships play a crucial role as well (Perrini - Tencati, 2006). What makes innovation pro-sustainable is disputed. Two streams of literature can be identified: i) innovation designed to reduce the environmental impact of economic activities, and ii) any innovation that reduces environmental load, independent of the original goal of the innovation (Zilahy - Széchy, 2012).

The growing area of business model (BM) research shows that BMs can be among the most effective tools for creating systemic change (Doganova - Eyquem-Renault, 2009; Yip - Bocken, 2018; Bocken et al., 2014). A BM describes how an organization creates, delivers and capture value (Osterwalder - Pigneur, 2010). BM describe the 
mechanism of value creation which needs to be aligned with the strategy of the organization (Móricz, 2007), and defines a series of activities that use the resources, partners, and assets of the corporation to establish and keep a competitive advantage (Chesbrough, 2007; Horváth - Móricz - Szabó, 2018). The sharing economy and industrial symbiosis are two examples of new business models whereby organizations can make a profit while significantly reducing industry's social and environmental footprint (Zilahy, 2016). Another example of new BM is Creating Shared Value (CSV). CSV motivates corporations to create alternative means of making a profit by solving environmentally important problems (Porter - Kramer, 2011).

The business opportunity to improve the financial inclusion of the currently non-or underbanked population and the TBL concept represent a new set of business models in the financial sector. Since Prahalad drew attention to the significant economic group of almost four billion people living below 3,000 USD capita/year - what he called the Bottom-of-the Pyramid - many new businesses and startup companies have emerged to offer services to this low-income, but populous economic group. The future economic potential of this group may be significant, but companies that would like to be successful at offering the former their services need to adapt their current business models (Tate - Bals, 2016). Critics have remarked that Prahalad's approach to connecting the BoP and large multinational companies will not necessarily be beneficial, as multinationals are less focused on social concerns and empowering individuals at the BoP, and rather on trying to sell their products (Calton et al., 2013). This lack of both empathy and proximity to end users of multinationals has created a market niche in which smaller, more agile companies may have a business case. Fintechs have created viable business models to offer financial services to the BoP by using technology.

The goal of the present research is to fill the gap in the existing literature by offering an analytical framework for assessing fintechs from a TBL-value-creation perspective. The author collected, analyzed and ranked available literature on sustainable banking, business modeling, corporate sustainability and fintechs based on their relevance, explanatory power, and presented empirical research. Articles were also analyzed from a topic relevance perspective. During the research a well-defined, yet populous social group - the BoP was selected, as this group faces with the most critical economic, social and environmental issues, with limited access to financial services.

To create the proposed Triple-Bottom-Line Impact Analysis Framework of Fintech Companies the author carried out a desk research to find and analyze fintech companies that already have a working business model and hence impact on the BoP. More than hundred fintech companies were analyzed from publicly available information, including websites, press releases, and previous researches. Using the fintech business model categories of Lee and Shin, fintechs were grouped into domains. Table 2 presents the results of the fintechs found in each domain. It was not the goal of the research to find or analyze all available fintech companies - the number ranges in the thousands -, but to collect a large enough sample to identify common patterns with regard to the TBL approach. Insurtech companies - technology companies that provide insurance services - were not included in the current research to keep the focus on core banking related services, yet the author believes that the proposed framework will be beneficial to these companies too. The author also analyzed existing sustainability frameworks in order to assess the gaps between current recommendations targeting large banks and FIs.

Section 1 gives an overview of the relationship between SD and corporations. Section 2 focuses on the involvement and role of financial institutions in SD. Section 3 shows how newly emerging fintech companies are already providing services and increasing the financial inclusion of previously non- or underbanked populations by creating new business models and tailor-made services. Section 4 describes existing sustainable banking frameworks with a short description of each. Section 5 presents the proposed TBL Impact Analysis Framework for Fintechs. Section 6 concludes.

\section{Sustainability in the financial sector}

Financial institutions (FI), or more specifically, banks, have big impact on SD due to their intermediary role between savers and borrowers and also their role in financing economic projects, corporate innovation and investment. Banks have both a direct and indirect impact on SD. Internal or direct effects are easy to see: office buildings, bricks-and-mortar branches, paper use, waste management and energy consumption. External (or indirect) impacts can outweigh direct impacts, and include the criteria for project finance, new service and product development (Jeucken - Bouma, 2017), and social inclusion.

FIs are similar to other companies in pursuing innovation, as their survival depends on it. When companies integrate sustainability considerations (environmental, social and financial goals) into their idea generation, research and development (R\&D) and commercialization activities, they are creating sustainable innovation. These innovations include products, services and technologies, as well as new business and organizational models (Charter et al., 2008). The company's mission is a critical element of its commitment to $\mathrm{SD}$, as it has a cascading effect on its strategy, business models and executable business road-maps (Dees, 1998). Environmental and social considerations today are often lacking in strategy making, reaching only a local optimum with a focus on economic gain. Applying Porter's diamond model to FIs implies that banks can achieve a competitive advantage if they have a better understanding of their strategy and underlying structure, market and customer demand, factor conditions, and related and supporting industries than their competitors. A growing number of companies understand the increasing demand for social and environmentally conscious services and are making a strategic shift to integrate sustainability into their businesses (Neven - Droge, 
2001). Companies, including FIs, are trying to rationalize their involvement in SD, but the relationship between TBL perspectives and financial return is complex. To succeed, organizations need to integrate the three building blocks of a pro-sustainability business case: i) they need to voluntarily participate in SD and understand the motives behind such initiatives, ii) the related business case must create positive, and observable economic benefits for the company, and iii) the company needs to embrace such business cases at the management level (Schaltegger - LüdekeFreund - Hansen, 2012). Table 1 presents two approaches FIs can take in their strategic transformation when dealing with sustainability. Baumgartner and Ebner's framework is more generalized, yet can be applied to FIs as well, meanwhile Jeucken specifically examined FIs during its research. Meanwhile there are differences in the exact content in the phases, the overall findings are strongly correlated.

Table 1.

Four strategic phases of corporate sustainability transformation

\begin{tabular}{|c|c|c|}
\hline & $\begin{array}{c}\text { Baumgartner - Ebner, } \\
2010\end{array}$ & Jeucken, 2010 \\
\hline Phase 1 & $\begin{array}{l}\text { Introverted strategy, with } \\
\text { focus on risk mitigation } \\
\text { and meeting minimum } \\
\text { legal compliance. }\end{array}$ & $\begin{array}{l}\text { Defensive banking, } \\
\text { where the bank only does } \\
\text { the absolute minimum to } \\
\text { meet regulatory expec- } \\
\text { tations. }\end{array}$ \\
\hline Phase 2 & $\begin{array}{l}\text { Increasingly extroverted } \\
\text { strategy, with improved } \\
\text { external relationships } \\
\text { and networks (e.g. } \\
\text { NGOs) in sustainability. }\end{array}$ & $\begin{array}{l}\text { Preventive banking, } \\
\text { where the bank identifies } \\
\text { cost-saving opportu- } \\
\text { nities and implements } \\
\text { measures within its own } \\
\text { operations (e.g. reducing } \\
\text { paper use, or energy } \\
\text { consumption). }\end{array}$ \\
\hline Phase 3 & $\begin{array}{l}\text { Cleaner production with } \\
\text { removing waste creation } \\
\text { through the entire life- } \\
\text { cycle. }\end{array}$ & $\begin{array}{l}\text { Offensive banking, } \\
\text { when the bank includes } \\
\text { sustainability in its ex- } \\
\text { ternal marketplace and } \\
\text { identifies viable business } \\
\text { cases. }\end{array}$ \\
\hline Phase 4 & $\begin{array}{l}\text { Holistic corporate strat- } \\
\text { egy wherein competitive } \\
\text { advantage is derived } \\
\text { from triple-bottom-line } \\
\text { considerations. }\end{array}$ & $\begin{array}{l}\text { Sustainable banking, } \\
\text { when the bank stream- } \\
\text { lines all its operations } \\
\text { and defines a clear strate- } \\
\text { gy in promoting sustain- } \\
\text { able development. }\end{array}$ \\
\hline
\end{tabular}

Source: Author's own table, based on Baumgartner - Ebner (2010) and Jeucken (2010)

The global financial crisis has drawn greater attention to FIs and made it apparent that most traditional banks have been overly focused on making economic gains but failed at social and environmental value creation and can be regarded as financial locusts. This failure of traditional banks has created a market niche for new business models. New financial services, product and asset classes have emerged as philanthropic, high-net-worth individuals, institutional investors and social banks, alongside specialized intermediaries and investors, became more dominant. Social banks are an important part of sustainability as they connect socially minded investors with borrowers. Evidence shows that social banking can be good business: reciprocity involving the repayment of loans is greater, and the bank can leverage the trust and common values it shares with the communities it serves in its new product development and distribution processes. Social banks are also less subject to moral hazard and bank defaults (Cornee - Szafarz, 2013). As a result, sustainability in finance is globally expanding, and new service providers are gaining competitive advantages by understanding better geographical boundaries and topological attributes and incorporating these insights into their product and service development (Langley, 2018).

The Green Investment Incentive Scheme, the Environmental Council for the Banking Sector, and UNEP's declarations on banking and the environment are examples of the increased focus of Western economies on improving global financial inclusion and its role in social and environmental value creation. The Financial Initiative of the United Nations Environmental Programme (UNEP) is playing an important role in promoting sustainable banking. Sustainable banking involves all levels of the organization, and banks need to take proactive measures and discover their own business case when attempting to engage with SD. Banks must also frequently engage with their stakeholders and shareholders on the topic of SD. Areas that banks can consider making more sustainable include the composition of business portfolios, the innovation focus on new products, entering new market segments such as the BoP, introducing green sales and marketing, and moving towards sustainable value chain, sustainable operations, and risk management (UNEP Finance Initiative, 2016).

Banks have also improved their engagement is green and climate finance. Green and climate finance is defined in many ways, but in general refers to financial instruments or investments that finance the delivery of positive environmental projects. While a growing area, its impact is less than expected. In 2014, 361 billion USD was invested in climate finance, from which only 124 million USD came from the private sector. Green and climate finance would require 1.6 trillion USD a year of investment. Socially Responsible Investment (SRI), which is a broader category than green finance, has become a 2.4 trillion USD industry. SRI involves social investing, social screening, community investing and shareholder activism (Tulchin, 2003).

The International Finance Corporation estimates that there will be 23 trillion USD of climate investment opportunities between 2016-2030 (Clark - Reed - Sunderland, 2018). Current barriers in the sector to investment include information and financing gaps, short-termism, the undervaluation of natural capital, and the lack of voluntary financial commitments. Strong evidence of successful projects, monitoring, reports and the addressing of infor- 
mation gaps is needed to help rationalize the benefits of green finance (Clark - Reed - Sunderland, 2018).

The birth of Microfinance Institutions (MFI) such as Grameen bank is a good example of successful business model innovation in the financial sector. A TBL-conscious financial business model must focus on the needs of local communities (Sinkovics - Sinkovics - Yamin, 2014). Sustainable value creation and delivery must include business processes, capabilities, and the stakeholder contribution (Morioka - Evans - de Carvalho, 2016). For the impacts of the MFI business model, Prof. Yunus, founder of Grameen, was awarded the Nobel Peace prize in 2006. MFIs have become widespread since their early days, with more than 3,300 institutions globally. Since its establishment in 1976, Grameen has grown into a group of 30 microfinance-related companies and organizations and has provided loans to 75 million people living at the BoP, $97 \%$ of whom are women (Yunus - Moingeon - LehmannOrtega, 2010).

The success of MFIs shows the demand for products that enable previously unbanked populations to access basic financial services. While MFIs are successful at providing a specific service - micro loans to previously unbanked -, there are also limitations to these products. First, a credit-driven service such as micro loans is not affordable to the poorest individuals who do not want to further burden themselves with debt or lack the business acumen needed to start even a micro business. MFIs are also dependent on external financing, and need to collect funds to distribute through their lending activities. MFIs need to repay their investors with profit, resulting in higher-than-market interest rates for their customers (Hammill - Matthew - McCarter, 2008). Nevertheless, microfinance and MFIs have been grown at an annual average rate of $30 \%$ over the past ten years to serve 66.7 million customers globally. Although MFIs are proof of the success of investing into the BoP, there is still an approximate funding gap of an order of magnitude. The annual cash demand in the sector is estimated to be 5 billion USD a year, compared to the current 500 million to 1 billion USD that is available.

\section{The role of Fintechs in sustainability}

"Fintech refers to non- or not fully regulated ventures whose goal is to develop novel, technology-enabled financial services with a value-added design that will transform traditional financial practices" (Varga, 2017) - or using a broader, more inclusive definition: "Fintech is a new financial industry that applies technology to improve financial activities" (Schueffel, 2016). This study uses the definition of Varga, as an overly broad definition makes it harder to distinguish Fintech from traditional banks - or large, multinational corporations. In theory, it would be possible to include banks or large companies in the present research, but this would make it harder to draw the line between traditional market participants and fintechs. This research has a focus on companies which are not regulated in terms of banking licenses, and tend towards what are called startup companies with innovative, often disruptive business models. Although not multinational conglomerates, fintechs are not always under-resourced companies. More than 50 billion dollars were invested into the sector between 2010 and 2016 (Schueffel, 2016; Varga, 2017).

Fintechs are often described as companies that focus on the high digital literacy Y generation. Fintechs quickly became successful in areas such as payment and lending, fueled by the loss of faith in traditional banks and lack of credit on the market. Novel technologies such as blockchain offer the promise of improving remittance transfers and decreasing transfer and operating costs. Fintechs are already an important driver of new financial services in areas such as banking, insurance, asset management and financial education (Kerényi, 2017), and also in other strategic financial domains involving the development of new services and products such as payments systems, billing, personal finance, online and mobile banking, direct lending, P2P lending, money transfer and cryptocurrency transfer (KPMG, 2017).

The role of fintechs in providing financial service to formerly non- or underbanked populations is rarely mentioned, and nor was this the focus of research. The success of fintechs at serving the $\mathrm{Y}$ generation is apparent, but their impact from a TBL perspective may be even more significant from an economic and social perspective. There are numerous successful examples of how fintechs have been able to improve financial inclusion by offering financial services to groups and geographic areas where traditional banks have failed to do so. Fintechs aim to stay in close proximity to their end-users and to understand the real demands of local communities, which results in more tailor-made solutions. Fintechs gain a competitive advantage as they consciously and continuously adapt to the requirements of specific social groups, thereby improving their social scaling ability. Scaling of the social impact of fintechs can occur in two dimensions: 1) depth scaling: by increasing the fit of a product or service value proposition through more accurate and faster needs recognition and by mobilizing action about social and environmental issues, resulting in the creation of more adaptive products and services, 2) breadth scaling: by increasing the number of people with access to services, creating synergies and networks, and improving access to formerly unreached beneficiaries. Fintechs are using ICT as an enabler to foster both dimensions of social scaling, creating positive social value. Although economists agree that social value is hard to concretize, there is a consensus that such services improve way of life, culture, community, politics, environment, health and well-being, personal and property rights and aspirations (Mulgan, 2010; Vanclay, 2003; Fisac Garcia et al., 2013), helping people live life to its full potential (Yunus, 2007).

New services such as cell-phone-enabled payment solutions and remittance transfers are powerful examples of this. Today, the availability of services has become more important to users than who provides them. The financial deepening offered by fintechs can help diminish extreme poverty by providing usable and simplistic yet 
affordable solutions to extreme users, such as those living at the BoP. Creating more efficient markets is critical from the perspective of SD and is among the eight Millennium Development Goals (Beck et al., 2011). Fintechs understand that companies need a servant leadership approach to be successful in this specialized market. The attributes of servant leadership are listening, empathy, healing, awareness, persuasion, conceptualization, foresight, stewardship, sense of community, and commitment to the growth of employees (Gupta, 2013). Fintech appears to understand these concepts better than traditional banks and is able to redefine how one moves money from one point to another in emerging markets, where the velocity of money is currently very slow (Hughes - Lonie, 2007).

Understanding why some fintechs became successful and large banks fail is useful when creating a framework for a general assessment of TBL in fintechs. Nairobi is often called the FinTech hub of emerging markets, and the cradle for one of the most illustrious fintech ventures at the BoP, called M-Pesa. M-Pesa was among the first ventures to draw attention to the power of fintech and its TBL impact. M-Pesa is a payment solution to enable cash transfer via mobile phones between M-Pesa account holders. The service was launched in Kenya in 2007 by Safaricom, a Vodafone subsidiary company. The service were quickly growing with approximately 17 million accounts in 2012 .

Some important and generalizable remarks can be made about the success factors of M-Pesa: 1) fintech's general target audience or customer segment may include a lower socio-economic demographic group than traditional financial institutions due to the lower costs of scaling via technology, 2) Kenya had over 90\% mobile phone penetration by 2016, enabling rapid customer adoption, 3) Kenya's median population age is 19.5 years, while $60 \%$ of its inhabitants are under 25. It is thus one of the youngest countries in the world, 4) Kenya has a role as regional economic leader, hosting large technology companies such as Google, 5) The country's population has fast internet due to appropriate network infrastructure (Blythin-Hammond - Van Cooten, 2017). These findings show that the development of local market conditions and tailor-made fintech solutions must fit the environment - fintech alone cannot change a market if there is no support from the broader economy and technological enablers, such as mobile phone penetration or fast internet. One of the most important findings about the success of M-Pesa is their success with understanding local markets and creating a service that truly serves the local community. "First world" solutions have been ignored and field studies undertaken to understand local conditions (Hughes - Lonie, 2007). The marketing of services also needs to be changed, with messages such as thinking together, learning and doing, building social capital, building connectivity, integration, and illustrating with examples (Bharti et al., 2014).

\section{Fintechs with TBL business models}

From a business model perspective, fintechs can generally be categorized into one of the following six domains: pay- ment, wealth management, crowdfunding, lending, capital markets, and insurance services (Lee - Shin, 2018).

Table 2.

Fintech companies and business models

\begin{tabular}{|c|c|}
\hline Business model & Name of Fintech \\
\hline Capital Markets & $\begin{array}{l}\text { Abacus, Abra, Acorns, Kapitall, Lelapa } \\
\text { Fund, Socure, Taqanu, WeSwap }\end{array}$ \\
\hline Crowdfunding & GoFundMe \\
\hline Lending & $\begin{array}{l}\text { Aire.io, Avant, Bondora, Borrowell, } \\
\text { Branch, CommonBond, Credit Karma, } \\
\text { Earnest, GuiaBolso, Harmoney, Tala, } \\
\text { Kiva, Kreditech, Landbay, lantouzi. } \\
\text { com, Lenddo, Lendify, LendingWorks, } \\
\text { LendInvest, LendUp, Lendwithcare, } \\
\text { Lufax.com, MaTontine, Mimoni, OnDeck, } \\
\text { Payoff, Peerform, Progressa, Prosper, } \\
\text { RateSetter, Sindeo, smava, SocietyOne, } \\
\text { Sofi, Tala, Umati Capital, Upstart, Wonga }\end{array}$ \\
\hline Payment & $\begin{array}{l}\text { Aspiration, Azimo, BitPesa, bKash, } \\
\text { Bloom, Doxo, Dwolla, Even Financial, } \\
\text { ftcash, Humaniq, Jimu, Juba Express, } \\
\text { M-Pesa, MODE, Modest Needs, Money } \\
\text { Forward, monyq, N26, Paganza, PaySe, } \\
\text { Pennies, PesaPal, Perfios, Prism, Remitly, } \\
\text { Simpl, Simple, Slicepay, TransferWise, } \\
\text { WorldRemit, Xoom }\end{array}$ \\
\hline $\begin{array}{l}\text { Wealth } \\
\text { Management }\end{array}$ & $\begin{array}{l}\text { Betterment, digit, DriveWealth, eToro, } \\
\text { Hedgeable, Koho, Levanto Financial, } \\
\text { Motif, Nest Wealth, Robinhood, SigFig, } \\
\text { Stash, Stockpile, Tink, Wealthfront, } \\
\text { Wealthsimple, WiseBanyan }\end{array}$ \\
\hline Other & Amply, DueDil, Onfido, Trulioo \\
\hline
\end{tabular}

Hundred selected fintechs were analyzed with the goal to identify fintechs whose business models could either directly or indirectly be associated with TBL principles in some aspects of their operations. In general, companies who targeted the under-or unbanked or the BoP segment used a strategy of promoting strong visual images with rural African or Indian populations. In some cases, the websites clearly stated the companies' missions. The mission of Kreditech, a credit-scoring fintech, is "Banking the Underbanked." In other cases, the targeted user group or the primary location of the service were used as an impact factor. Fintechs which appeared to be aiming to improve the financial inclusion of African, Indian, or other countries - or underbanked populations were selected. Some fintech companies provided services globally, although their minimum investment was specified as being thousands of dollars. These companies were excluded - although technically they may also provide services to rural areas, the cost of the service and the entry threshold is generally too high for people living at the BoP. Wealth management services were thus also excluded, as according to the information on their websites their primary tar- 
get customers are members of the wealthier population with sound financial literacy and some savings. In cases when product or services were described as being easy to access with a low barrier to entry, the goal of financial inclusion was most apparent. Services that linked Western lenders to BoP borrowers were also categorized as companies with TBL impact, as these services further improve the credit available to microfinance local businesses. As a caveat to the selection process of fintech from a TBL perspective, the following facts should be noted: First, company websites were not always organized along clear lines so as to allow identification of whether they have a direct or non-direct TBL impact, thus it is possible that some companies were excluded from the sample - and that companies with a questionable impact were included. Second, it was found to hard any references or feedback from users who actually use the related services, thus it was difficult to identify whether the service is actually accomplishing its goals. An overview of the companies which were categorized as having TBL impact is included in Table 3, with a short description of each:

Table 3.

\section{Fintechs with TBL value-creation elements}

\begin{tabular}{|c|c|c|}
\hline Name & Category & Description \\
\hline Abacus & $\begin{array}{l}\text { Capital } \\
\text { markets }\end{array}$ & $\begin{array}{l}\text { A web and mobile software that helps investors } \\
\text { across the globe access African financial markets. }\end{array}$ \\
\hline $\begin{array}{l}\text { Lelapa } \\
\text { Fund }\end{array}$ & $\begin{array}{l}\text { Capital } \\
\text { markets }\end{array}$ & $\begin{array}{l}\text { An investment platform that connects global in- } \\
\text { vestors with African growth ventures. }\end{array}$ \\
\hline GoFundMe & $\begin{array}{l}\text { Capital } \\
\text { markets }\end{array}$ & $\begin{array}{l}\text { The world's largest social fundraising platform, } \\
\text { having raised over } \$ 5 \text { billion USD. A community } \\
\text { of more than } 50 \text { million donors. }\end{array}$ \\
\hline Amply & Other & $\begin{array}{l}\text { Digital identity service. Received seed investment } \\
\text { from UNICEF's new innovation fund. The service } \\
\text { strives to revolutionize early childhood develop- } \\
\text { ment in Africa. Combines mobile and blockchain } \\
\text { technology. }\end{array}$ \\
\hline Taqanu & $\begin{array}{l}\text { Digital } \\
\text { Identity }\end{array}$ & $\begin{array}{l}\text { Digital identity solution, using blockchain tech- } \\
\text { nology. }\end{array}$ \\
\hline Trulioo & Other & $\begin{array}{l}\text { Digital identity service. It has developed a global } \\
\text { ID verification solution to help verify } 4.5 \text { billion } \\
\text { people and } 250 \text { million } \\
\text { companies in over } 100 \text { countries. }\end{array}$ \\
\hline Aire.io & Lending & Credit risk profiling for the BoP. \\
\hline Branch & Lending & $\begin{array}{l}\text { Lending services in San Francisco, Nairobi, Lagos } \\
\text { and Mumbai. Lending is based on data collected } \\
\text { (with permission) from mobile phones, GPS data, } \\
\text { call logs, social network data, contact lists. }\end{array}$ \\
\hline GuiaBolso & Lending & Low-rate lending. Available only in Brazil. \\
\hline Kiva & Lending & $\begin{array}{l}\text { An international nonprofit, founded in } 2005 \text {. The } \\
\text { mission is to connect people through lending to } \\
\text { alleviate poverty. Microlending starts from } 25 \text { dol- } \\
\text { lars, with } 2.8 \text { million borrowers in } 86 \text { countries. }\end{array}$ \\
\hline Kreditech & Lending & $\begin{array}{l}\text { The mission is to provide banking to the under- } \\
\text { banked. Targets two billion adults worldwide who } \\
\text { are underbanked. Three hundred employees from } \\
40 \text { nations at seven office locations. }\end{array}$ \\
\hline Lenddo & Lending & $\begin{array}{l}\text { Creating credit scores to improve the lives of the } \\
\text { emerging middle class in developing countries by } \\
\text { providing micro loans for specific purposes. }\end{array}$ \\
\hline
\end{tabular}

\begin{tabular}{|c|c|c|}
\hline $\begin{array}{l}\text { Lend- } \\
\text { withcare }\end{array}$ & Lending & $\begin{array}{l}\text { Lending platform which lends a minimum of } 15 \\
\text { pounds to fund a small business and support poor } \\
\text { entrepreneurs. }\end{array}$ \\
\hline MaTontine & Lending & $\begin{array}{l}\text { Lending services for the financially excluded earn- } \\
\text { ing less than } \$ 5 / \text { day. }\end{array}$ \\
\hline Tala & Lending & $\begin{array}{l}\text { Credit scoring and lending with a new credit } \\
\text { scoring model based on thousands of mobile data } \\
\text { points, including network diversity, social con- } \\
\text { nectedness, geographic patterns, and financial } \\
\text { transactions. }\end{array}$ \\
\hline $\begin{array}{l}\text { Umati } \\
\text { Capital }\end{array}$ & Lending & Offers a variety of credit products. \\
\hline Wonga & Lending & $\begin{array}{l}\text { Short-term cash flow management service in } \\
\text { South Africa, Poland and Spain. }\end{array}$ \\
\hline Aspiration & Payment & $\begin{array}{l}\text { Payment solution with built-in donations for char- } \\
\text { itable causes. }\end{array}$ \\
\hline Azimo & Payment & $\begin{array}{l}\text { fer company whose goal is to make } \\
\text { is simpler and more cost effective. }\end{array}$ \\
\hline BitPesa & Payment & $\begin{array}{l}\text { Payment startup. Present in } 85 \text { countries, with } \\
6,000 \text { users. }\end{array}$ \\
\hline bKash & Payment & $\begin{array}{l}\text { bKash is a payment service owned by BRAC } \\
\text { Bank. Available only in Bangladesh. }\end{array}$ \\
\hline ftcash & Payment & $\begin{array}{l}\text { ftcash is a financial services company which } \\
\text { started operating in } 2015 \text {, and is headquartered in } \\
\text { Mumbai, India. The goal of ftcash is to empower } \\
\text { micro-merchants through digital payments and } \\
\text { loans. }\end{array}$ \\
\hline Humaniq & Payment & $\begin{array}{l}\text { Humaniq is a services platform with its own cryp- } \\
\text { tocurrency. Its goal is to power the unbanked. The } \\
\text { service already has } 129,000 \text { members. }\end{array}$ \\
\hline M-Pesa & Payment & $\begin{array}{l}\text { Payment services provider in Kenya. M-Pesa is } \\
\text { fully regulated. }\end{array}$ \\
\hline MODE & Payment & $\begin{array}{l}\text { MODE operates in } 31 \text { countries with a customer } \\
\text { base of over } 250 \text { million. Loans and remittance } \\
\text { transfers are the key focus: Countries include: } \\
\text { Kenya, India, Nigeria, Mauritius, UAE, Uganda, } \\
\text { South Africa, Cameroon. }\end{array}$ \\
\hline $\begin{array}{l}\text { Modest } \\
\text { Needs }\end{array}$ & Payment & $\begin{array}{l}\text { Modest Needs makes small, emergency grants to } \\
\text { low-income workers who are at risk of slipping } \\
\text { into poverty. }\end{array}$ \\
\hline PaySe & Payment & $\begin{array}{l}\text { Winner of payment system innovation India. } \\
\text { Blockchain solution. }\end{array}$ \\
\hline Pennies & Payment & $\begin{array}{l}\text { Pennies is the digital upgrade of the traditional } \\
\text { charity box. It helps with donating a few pence to } \\
\text { charity when paying by bank card. }\end{array}$ \\
\hline PesaPal & Payment & $\begin{array}{l}\text { An African fintech which helps to make and ac- } \\
\text { cepts individual and business-related payments in } \\
\text { Africa. }\end{array}$ \\
\hline Slicepay & Payment & $\begin{array}{l}\text { A digital payment platform with a mission of } \\
\text { simplifying payments for the young. Available in } \\
\text { India only. }\end{array}$ \\
\hline
\end{tabular}

Source: Author's construction based on information publicly available on company websites

\section{Sustainable banking frameworks}

Sustainable banking frameworks and organizations that are working to provide guidelines for sustainable banking do exist. Some of the most important ones include the Alliance for Financial Inclusion, the Equator Principles, the Global Impact Investing Network's Impact Reporting and Investment Standards, The London Principles of Sustainable Finance, the SIGMA Guiding Principles, the UNEP's FI Statement by Financial Institutions, and the US's Social Investment Forum. The different frameworks, 
guidelines, and indicators have different merits, and a short summary of each of them is provided in Table 4. Current frameworks were designed with large FIs in mind with a focus on traditional bricks-and-mortar banking and project financing of millions of dollars. The limitations of these frameworks are apparent: they create extra planning, reporting and execution overheads for companies, thus only large FIs can use them. Their use in fintechs is restricted due to their size, available resources and organizational maturity. However, while the frameworks include elements about both the direct and indirect factors that affect the TBL of financial institutions to varying degrees, these are mostly related to tangible internal and external impacts and exclude factors such as social scaling and financial inclusion. The inclusion of indirect factors such as dynamic capabilities, innovation, knowledge, human resources, intellectual capital, and information technology, among others, are often missing from the guidelines (Tsai - Tsai - Chang, 2013).

Table 4. Sustainable banking frameworks and organizations

\begin{tabular}{|c|c|}
\hline $\begin{array}{c}\text { Organization / } \\
\text { Principles }\end{array}$ & Description \\
\hline $\begin{array}{l}\text { Alliance for } \\
\text { Financial Inclusion } \\
(\text { AFI })\end{array}$ & $\begin{array}{l}\text { A global knowledge exchange platform for } \\
\text { improving financial inclusion policy, and help- } \\
\text { ing policymakers to increase access to quality } \\
\text { financial services for the poorest populations. }\end{array}$ \\
\hline $\begin{array}{l}\text { Equator Principles } \\
\text { (EPs) }\end{array}$ & $\begin{array}{l}\text { EPs apply to Project Finance Advisory Services } \\
\text { when total project capital costs are US } \$ 10 \text { mil- } \\
\text { lion or more; Project Finance with total project } \\
\text { capital costs of US } \$ 10 \text { million or more; Project- } \\
\text { Related Corporate Loans in an aggregate } \\
\text { amount of at least } 100 \text { million USD. Ninety-two } \\
\text { financial institutions (EPFIs) have adopted the } \\
\text { EPs in } 37 \text { countries. }\end{array}$ \\
\hline $\begin{array}{l}\text { Global Alliance for } \\
\text { Banking on Values } \\
(\text { GABV) }\end{array}$ & $\begin{array}{l}\text { A network of banking leaders from around the } \\
\text { world committed to advancing positive change } \\
\text { in the banking sector, in which the TBL ap- } \\
\text { proach sits at the heart of the business model } \\
\text { of the bank. }\end{array}$ \\
\hline $\begin{array}{l}\text { Global Impact } \\
\text { Investing Network } \\
\text { (GIIN) }\end{array}$ & $\begin{array}{l}\text { Network for impact investing powered by in- } \\
\text { vestors who are determined to generate social } \\
\text { and environmental impact as well as financial } \\
\text { returns. Five key values of GIIN are: Responsible } \\
\text { Leadership, Intellectual Rigor \& Curiosity \& } \\
\text { Excellence, Learning \& Adaptation, Diversity of } \\
\text { Perspectives, Team Spirit. } \\
\end{array}$ \\
\hline $\begin{array}{l}\text { GRI Sustainability } \\
\text { Reporting } \\
\text { Standards }\end{array}$ & $\begin{array}{l}\text { The most widely adopted global standards for } \\
\text { sustainability reporting. Ninety-three per cent } \\
\text { of the world's largest } 250 \text { corporations report } \\
\text { on their sustainability performance based on } \\
\text { GRI. }\end{array}$ \\
\hline $\begin{array}{l}\text { Social Return on } \\
\text { Investment (SROI) }\end{array}$ & $\begin{array}{l}\text { SROI was developed by the Roberts Enterprise } \\
\text { Development Fund (REDF) in the United } \\
\text { States in the mid-1990s. It has a focus on ex- } \\
\text { pressing social benefits in monetary terms by } \\
\text { using contingent valuation methods, such as } \\
\text { willingness to pay and willingness to accept. }\end{array}$ \\
\hline
\end{tabular}

\begin{tabular}{|c|c|}
\hline $\begin{array}{l}\text { The London } \\
\text { Principles of } \\
\text { Sustainable Finance }\end{array}$ & $\begin{array}{l}\text { The London Principles were launched by Tony } \\
\text { Blair at the Johannesburg summit in } 2002 \text {. The } \\
\text { goal of the London Principles is to demonstrate } \\
\text { good practice through case studies of a number } \\
\text { of UK-based financial institutions through a } \\
\text { voluntary code and set of seven principles for } \\
\text { financial institutions. }\end{array}$ \\
\hline $\begin{array}{l}\text { The SIGMA } \\
\text { Guiding Principles }\end{array}$ & $\begin{array}{l}\text { The SIGMA Project was launched in } 1999 \text { by } \\
\text { the British Standards Institute, Forum for the } \\
\text { Future, and AccountAbility with the goal of } \\
\text { preserving the five capitals: Natural capital, } \\
\text { Social capital, Human capital, Manufactured } \\
\text { capital, Financial capital. }\end{array}$ \\
\hline $\begin{array}{l}\text { UNEP FI Statement } \\
\text { by Financial } \\
\text { Institutions }\end{array}$ & $\begin{array}{l}\text { Members include } 200 \text { financial institutions, } \\
\text { including banks, insurers, and investors, } \\
\text { working with UN Environment to understand } \\
\text { today's environmental, social and governance } \\
\text { challenges. }\end{array}$ \\
\hline $\begin{array}{l}\text { US Social } \\
\text { Investment Forum } \\
\text { (US SIF) }\end{array}$ & $\begin{array}{l}\text { The goal of US SIF is to advance sustainable, } \\
\text { responsible and impact investing across all } \\
\text { asset classes in the US, focusing on long-term } \\
\text { investment and the generation of positive } \\
\text { social and environmental impacts. Members } \\
\text { include investment management and advisory } \\
\text { firms, mutual fund companies, asset owners, } \\
\text { research firms, financial planners and advisors, } \\
\text { broker-dealers, community investing organiza- } \\
\text { tions and nonprofit organizations. }\end{array}$ \\
\hline $\begin{array}{l}\text { World Bank } \\
\text { Environmental and } \\
\text { Social Framework }\end{array}$ & $\begin{array}{l}\text { Defines the World Bank's criteria for assessing } \\
\text { projects with the aim of ending extreme pov- } \\
\text { erty and increasing shared prosperity. It re- } \\
\text { quires borrowers to report on: assessment and } \\
\text { management of environmental and social risks } \\
\text { and impacts, labor and working conditions, } \\
\text { resource efficiency and pollution prevention, } \\
\text { community health and safety, land acquisition, } \\
\text { biodiversity conservation, and several other } \\
\text { factors. }\end{array}$ \\
\hline
\end{tabular}

Source: Author's construction, based on publicly available information found on organizations' official websites

Current frameworks were designed to ensure that the reporting of large FIs is standardized based on criteria such as their internal operation and direct environmental impact, and through their products or services such as project financing. Such overly descriptive frameworks are not useful for assessing the impact of companies which often provide loans to the value of 25 dollars towards projects with an overall project value of a few thousand dollars. With such projects, factors such as environmental impact analysis, land acquisition, or biodiversity conservation must be assessed in a different manner. On the other hand, it is necessary to have a smaller scale, yet effective framework for fintechs as well, as these companies are often the first entry point for the involvement of the previously non- or underbanked in financial services and thus have a great impact on how these populations are educated about project criteria, or the use of finance. A framework is also useful if it is only voluntary, as it helps to guide new service or product development and gives companies the opportunity to make a statement by starting to report according to the criteria laid out in the framework. 


\section{TBL Impact Analysis Framework of Fintech}

The creation of a lightweight TBL Impact Analysis Framework for Fintechs has three benefits: First, operating ventures can assess their current way of doing business and can make an educated decision about whether they need to improve in some areas. Second, companies which are just in the process of defining their mission, strategy and business models can find support for integrating TBL perspectives into their core operations. Third, such a framework can be used as a guide to foster systemic innovation within the financial sector: it may help companies to create structured, voluntary reporting which can be used to develop future policies and considerations for investors that help them with investing decisions (such as which fintechs should they be investing in). As fintech are faster at prototyping new solutions than traditional banks, the impact of their TBL services can be a good indicator of the feasibility of large-scale adoption by traditional universal banks. Another fallacy of presently available frameworks is that they are not adopted to how small technology companies are modifying their business operations and developing services. Agile development, lean product and service development, business models, scaling through IT, and the use of design thinking techniques such as co-creation are the key value drivers behind their operations (Varga, 2017).

The TBL Impact Analysis Framework for Fintechs was created with the following principles in mind. It should be: 1) Easy to understand: TBL perspectives are clearly organized according to the three major categories, economic, social, and environmental value creation; 2) Gradually adoptable: to promote uptake of the framework it contains sets of areas in which companies can voluntary improve their TBL impact. There is no need to adopt or to excel in all areas from the beginning; a company needs to continually assess and measure its progress against its goals and make improvements based on its findings. There is no universal business model or company structure that fits all - each company should design a strategy that fits its purposes best. On the other hand, there must be a scale for adoption to encourage further steps and development, therefore the framework offers three levels of depth: from Level 1 to 3. Another principle is: 3) Focus on holistic, controllable factors: current sustainability banking frameworks often focus on factors that are either taken out of context or not viewed holistically. The strategic elements which are under the control of the company must come first when improving the TBL impact of a company, as these factors will inherently change all related factors and procedures as well. Such an approach enables companies to integrate TBL principles into the core of their operations rather than view them as a reporting metric and a line on a spreadsheet. Core operations, value drivers and resources and capabilities should be aligned to deliver long-term sustainable benefits. TBL then becomes an integrated way of doing things: the reason "why" and explanation "how" a company behaves in their daily activities.
The goal of the proposed framework is to increase discussion and provide a starting point for fintech in their TBL journey. Based on their experiences and feedback, the framework can be adapted and modified as customers and fintechs companies discover areas for improvement. The value-creation items in the framework are based on current IT development and lean product development principles that have been adopted by fintechs and startup companies, and the literature on business modeling, open innovation and TBL that has already been described. The categorization of Level 1 to Level 3 is based on the author's perception of organizational development and will be adjusted to the specific company strategy. The frameworks are intended to offer a guideline, but not a prescriptive set of "must-haves," as each company must define its own optimum business case based on its company vision and mission. (Table 5.)

Table 5.

\section{TBL Impact Analysis Framework of Fintech Companies}

\begin{tabular}{|c|c|c|c|}
\hline Value creation & Level 1 & Level 2 & Level 3 \\
\hline \multicolumn{4}{|c|}{ Economic values } \\
\hline Business model & $\begin{array}{l}\text { Some of the } \\
\text { building blocks } \\
\text { but not the value } \\
\text { proposition } \\
\text { contains TBL } \\
\text { elements. }\end{array}$ & $\begin{array}{l}\text { TBL per- } \\
\text { spectives are } \\
\text { included in the } \\
\text { business model, } \\
\text { and also affect } \\
\text { the value propo- } \\
\text { sition. }\end{array}$ & $\begin{array}{l}\text { The value } \\
\text { proposition of } \\
\text { the company is } \\
\text { centered around } \\
\text { TBL value } \\
\text { creation. }\end{array}$ \\
\hline Mission & $\begin{array}{l}\text { TBL is not or } \\
\text { non-visibly an } \\
\text { integrated part } \\
\text { of the company's } \\
\text { mission. }\end{array}$ & $\begin{array}{l}\text { TBL is a clear- } \\
\text { ly articulated } \\
\text { element in the } \\
\text { company's } \\
\text { mission. }\end{array}$ & $\begin{array}{l}\text { TBL value } \\
\text { creation is the } \\
\text { core mission of } \\
\text { the company. }\end{array}$ \\
\hline $\begin{array}{l}\text { Organizational } \\
\text { model }\end{array}$ & $\begin{array}{l}\text { The company is } \\
\text { non-transparent } \\
\text { (publicly) about } \\
\text { its operating } \\
\text { principles. }\end{array}$ & $\begin{array}{l}\text { Company } \\
\text { shares internal } \\
\text { guidelines and } \\
\text { approaches with } \\
\text { public; em- } \\
\text { ployees are key } \\
\text { assets. } \\
\end{array}$ & $\begin{array}{l}\text { Company is } \\
\text { experiment- } \\
\text { ing with new } \\
\text { organizational } \\
\text { models, such as } \\
\text { holacracy. }\end{array}$ \\
\hline $\begin{array}{l}\text { Product } \\
\text { / Service } \\
\text { Development }\end{array}$ & $\begin{array}{l}\text { TBL perspec- } \\
\text { tives are not } \\
\text { integrated into } \\
\text { the design of } \\
\text { the product / } \\
\text { service. }\end{array}$ & $\begin{array}{l}\text { The company } \\
\text { articulates how } \\
\text { TBL is included } \\
\text { in the design } \\
\text { of the product / } \\
\text { service. }\end{array}$ & $\begin{array}{l}\text { The company } \\
\text { continuously } \\
\text { monitors, audits } \\
\text { and adapts its } \\
\text { products / ser- } \\
\text { vices to improve } \\
\text { TBL impact. }\end{array}$ \\
\hline $\begin{array}{l}\text { Profit distri- } \\
\text { bution }\end{array}$ & $\begin{array}{l}\text { The company } \\
\text { is focused on } \\
\text { maximizing ROI } \\
\text { with minimum } \\
\text { social effort. }\end{array}$ & \begin{tabular}{|l|} 
Some profit is \\
distributed to- \\
wards social and \\
environmental \\
goals.
\end{tabular} & $\begin{array}{l}\text { Large part of the } \\
\text { profit is distrib- } \\
\text { uted towards } \\
\text { social and envi- } \\
\text { ronmental goals. }\end{array}$ \\
\hline Reporting & $\begin{array}{l}\text { No reporting } \\
\text { about TBL } \\
\text { perspectives. }\end{array}$ & $\begin{array}{l}\text { Voluntary re- } \\
\text { porting without } \\
\text { external audit. }\end{array}$ & $\begin{array}{l}\text { External auditor } \\
\text { is involved in } \\
\text { reporting. }\end{array}$ \\
\hline Scaling & $\begin{array}{l}\text { Product / service } \\
\text { is hard to adopt } \\
\text { in different } \\
\text { markets as it re- } \\
\text { quires advanced } \\
\text { / or expensive } \\
\text { technology. }\end{array}$ & $\begin{array}{l}\text { Product / service } \\
\text { is designed to } \\
\text { scale up rapidly } \\
\text { due to conscious } \\
\text { use of hardware } \\
\text { or network } \\
\text { requirements. }\end{array}$ & $\begin{array}{l}\text { The company } \\
\text { actively analyses } \\
\text { and overcomes } \\
\text { restrictions on } \\
\text { product scaling: } \\
\text { e.g. provides } \\
\text { education. }\end{array}$ \\
\hline
\end{tabular}




\begin{tabular}{|c|c|c|c|}
\hline Service Fee & $\begin{array}{l}\text { Flat service fee, } \\
\text { with no differen- } \\
\text { tial factors built- } \\
\text { in, such as good } \\
\text { credit history or } \\
\text { purpose. }\end{array}$ & \begin{tabular}{|l} 
Service fee \\
includes differ- \\
ential pricing \\
with advanced, \\
tailor-made and \\
personalized \\
pricing. \\
\end{tabular} & $\begin{array}{l}\text { Service fee in- } \\
\text { cludes personal- } \\
\text { ized pricing, and } \\
\text { social / environ- } \\
\text { mental impact } \\
\text { calculation. }\end{array}$ \\
\hline \multicolumn{4}{|c|}{ Social values } \\
\hline $\begin{array}{l}\text { Access to } \\
\text { service }\end{array}$ & \begin{tabular}{|l|} 
Limited to cer- \\
tain groups due \\
to higher cost, \\
advanced tech- \\
nology, language \\
selection. \\
\end{tabular} & \begin{tabular}{|l|} 
The service \\
aims to increase \\
ease of access to \\
different social \\
and demograph- \\
ic groups. \\
\end{tabular} & \begin{tabular}{|l|} 
The service was \\
designed so even \\
BoP and under- \\
privileged social \\
groups can \\
access it easily. \\
\end{tabular} \\
\hline Cultural fit & $\begin{array}{l}\text { Service was } \\
\text { created without } \\
\text { consulting end } \\
\text { users. }\end{array}$ & $\begin{array}{l}\text { The service is } \\
\text { based on initial } \\
\text { field studies, and } \\
\text { research with } \\
\text { end-users. }\end{array}$ & $\begin{array}{l}\text { The service is } \\
\text { continuously } \\
\text { assessed and } \\
\text { adapted to im- } \\
\text { prove cultural } \\
\text { fit. } \\
\end{array}$ \\
\hline Literacy needs & $\begin{array}{l}\text { Complex prod- } \\
\text { uct/service with } \\
\text { high literacy } \\
\text { needs. }\end{array}$ & \begin{tabular}{|l|} 
Clear and un- \\
derstandable \\
service features, \\
but still complex \\
user interface. \\
\end{tabular} & \begin{tabular}{|l} 
Simplified, \\
easy to use user \\
interface, even \\
for non-schooled \\
groups. \\
\end{tabular} \\
\hline Partnerships & $\begin{array}{l}\text { No or very little } \\
\text { number of part- } \\
\text { nerships in the } \\
\text { area of sustaina- } \\
\text { bility. }\end{array}$ & $\begin{array}{l}\text { Some partner- } \\
\text { ships in the area } \\
\text { of sustainability } \\
\text { and local groups. }\end{array}$ & $\begin{array}{l}\text { Company is ac- } \\
\text { tively pursuing } \\
\text { and has estab- } \\
\text { lished active } \\
\text { local and global } \\
\text { partnerships. }\end{array}$ \\
\hline $\begin{array}{l}\text { Stakeholder } \\
\text { management }\end{array}$ & \begin{tabular}{|l|} 
No or little \\
active discussion \\
with stakehold- \\
ers, lack of clear \\
stakeholder \\
management \\
plan.
\end{tabular} & \begin{tabular}{|l|} 
Company has \\
a stakeholder \\
management \\
map and pursues \\
non-frequent \\
dialogue with its \\
stakeholders. \\
\end{tabular} & $\begin{array}{l}\text { Company is ac- } \\
\text { tively engaging } \\
\text { with its stake- } \\
\text { holders, building } \\
\text { common devel- } \\
\text { opment road- } \\
\text { maps together. } \\
\end{array}$ \\
\hline \multicolumn{4}{|c|}{ Environmental values } \\
\hline $\begin{array}{l}\text { Direct } \\
\text { Environmental } \\
\text { Impact }\end{array}$ & $\begin{array}{l}\text { No internal or } \\
\text { external carbon } \\
\text { footprint assess- } \\
\text { ment within the } \\
\text { company. }\end{array}$ & \begin{tabular}{|l|} 
Some measures, \\
including waste \\
management and \\
decreasing paper \\
use in its inter- \\
nal and external \\
processes. \\
\end{tabular} & $\begin{array}{l}\text { Holistic ap- } \\
\text { proach to mini- } \\
\text { mizing environ- } \\
\text { mental impact } \\
\text { throughout the } \\
\text { supply chain. }\end{array}$ \\
\hline $\begin{array}{l}\text { Indirect } \\
\text { Environmental } \\
\text { Impact }\end{array}$ & $\begin{array}{l}\text { The company } \\
\text { does not meas- } \\
\text { ure the indirect } \\
\text { environmental } \\
\text { impact of its } \\
\text { services. }\end{array}$ & $\begin{array}{l}\text { The company } \\
\text { requires some } \\
\text { information } \\
\text { about the envi- } \\
\text { ronmental im- } \\
\text { pact created by } \\
\text { its services. }\end{array}$ & $\begin{array}{l}\text { Company pro- } \\
\text { vides services } \\
\text { only to those } \\
\text { who meet its } \\
\text { explicit expecta- } \\
\text { tions regarding } \\
\text { the environ- } \\
\text { mental impact } \\
\text { created by its } \\
\text { services. }\end{array}$ \\
\hline $\begin{array}{l}\text { Environmental } \\
\text { Policy }\end{array}$ & $\begin{array}{l}\text { No environmen- } \\
\text { tal policy exists } \\
\text { within the com- } \\
\text { pany. }\end{array}$ & \begin{tabular}{|l|} 
There is a \\
guideline, but \\
no mandatory \\
policy within the \\
company.
\end{tabular} & $\begin{array}{l}\text { There is a } \\
\text { mandatory } \\
\text { environmental } \\
\text { policy within the } \\
\text { company. }\end{array}$ \\
\hline
\end{tabular}

\section{Conclusion}

During the research, four important findings were identified with regard to current sustainable baking frameworks and the role of fintech in TBL value creation: First, current sustainable banking frameworks are not unified, and are maintained by different organizations with no evidence of structured alignment between the different initiatives. The current frameworks in most cases lack the inclusion of small, innovative ventures, and only include universal banks and well-funded institutions. Maintaining too many different standards may have a counterproductive effect as it can cause confusion in the sector and make room for many alternative interpretations.

Second, traditional banks have failed to financially include some segregated groups, such as members of the BoP. Fintechs may be able to improve the current status quo and improve social and environmental value creation by using ICT and new business models. However, there is no currently available framework for assessing and promoting the TBL impact of fintechs. The creation of such a framework is an important goal, as fintechs can prove the viability of new business models, opening up opportunities for more risk-averse banks to invest into new areas of product development.

Third, during the analysis of more than hundred operating fintechs it became apparent that the public information provided by fintechs is often overly narrow or secretive. Their websites and other communication channels are not effective at conveying the TBL impact of their services. There are two possible explanations for this: Even those companies that provide services to the BoP or have a TBL impact are primarily interested in revenue creation, and the social and environmental impacts of their services are only an indirect effect of their primary activities. Second, fintech companies have not yet recognized the importance of clearly communicating the sustainability impact of their services. The communication of the companies under analysis is mostly focused on strong visual images, but TBL value creation is demonstrated only in a few cases in the company missions or other descriptive elements.

Fourth, to be effective a TBL Impact Analysis Framework for Fintechs needs to be tested and further researched based on empirical data and in cooperation with fintech companies. To gain the largest benefits the proposed framework needs to be taken out to the real world, where it is continuously measured and adjusted based on feedback from market participants.

\section{References}

Arvidson, M. - Lyon, F. - McKay, S. - Moro, D. (2013): Valuing the social? The nature and controversies of measuring social return on investment (SROI). Voluntary Sector Review, 4(1), p. 3-18.

Ashoka (2010): Ashoka fellows changing systems. Global Study 2009, http://sfs.ashoka.org/sites/ sfs/!les/2010\%20Ashoka\%20Impact\%20Study.pdf (accessed March 21, 2013).

Bandiera, O. - Hansen, S. - Prat, A. - Sadun, R. (2017): CEO Behavior and Firm Performance (No. w23248). National Bureau of Economic Research

Baumgartner, R. J. - Ebner, D. (2010): Corporate sustainability strategies: sustainability profiles and 
maturity levels. Sustainable Development, 18(2), p. 76-89.

Beck, T. - Maimbo, S. M. - Faye, I. - Triki, T. (2011): Financing Africa: Through the crisis and beyond. New York: World Bank

Bharti, K. - Sharma, V. - Agrawal, R. - Sengar, A. (2014): Marketer's Mindset: Key to Develop Bottom of the Pyramid Market. Procedia-Social and Behavioral Sciences, 133, p. 169-179.

Birkin, F. - Polesie, T. - Lewis, L. (2009): A new business model for sustainable development: an exploratory study using the theory of constraints in Nordic organizations. Business Strategy and the Environment, 18(5), p. 277-290.

Blythin-Hammond, J. - Van Cooten, J. (2017): The Development of FinTech in Nairobi: Contributions to Financial Inclusion and Barriers to Growth. Lund University. https://lup.lub.lu.se/student-papers/ search/publication/8917326, downloaded on: March 24, 2018

Bocken, N. M. - Short, S. W. - Rana, P. - Evans, S. (2014): A literature and practice review to develop sustainable business model archetypes. Journal of Cleaner Production, 65, p. 42-56.

Boons, F. - Lüdeke-Freund, F. (2013): Business models for sustainable innovation: state-of-the-art and steps towards a research agenda. Journal of Cleaner Production, 45, p. 9-19.

Boons, F. - Montalvo, C. - Quist, J. - Wagner, M. (2013): Sustainable innovation, business models and economic performance: an overview. Journal of Cleaner Production, 45, p. 1-8.

Calton, J. M. - Werhane, P. H. - Hartman, L. P. - Bevan, $D$. (2013): Building partnerships to create social and economic value at the base of the global development pyramid. Journal of Business Ethics, 117(4), p. 721-733.

Charter, M. - Gray, C. - Clark, T. - Woolman, T. (2008): Review: the role of business in realising sustainable consumption and production. System Innovation for Sustainability: Perspectives on Radical Changes to Sustainable Consumption and Production, p. 46-69.

Chesbrough, H.W. (2007): Business model innovation: it's not just about technology anymore. Strategy \& Leadership, 35(6), p. 12-17.

Clark, R. - Reed, J. - Sunderland, T. (2018): Bridging funding gaps for climate and sustainable development: Pitfalls, progress and potential of private finance. Land Use Policy, 71, p. 335-346.

Cooper, R. G. (1994): Perspective third-generation new product processes. Journal of Product Innovation Management, 11(1), p. 3-14.

Dees, J. G. (1998): The meaning of social entrepreneurship. Chicago

Doganova, L. - Eyquem-Renault, M. (2009): What do business models do?: Innovation devices in technology entrepreneurship. Research Policy, 38(10), p. 1559-1570.

Elkington, J. (2013): Enter the triple bottom line. In: The triple bottom line. London: Routledge, p. 23-38.
Fisac Garcia, R. - Acevedo Ruiz, M. - Moreno Romero, A. M. - Kreiner, T. (2013): The role of ICT in scaling up the impact of social enterprises. Journal of Management for Global Sustainability, 1(2), p. 83-105.

Gupta, S. (2013): Serving the" Bottom of Pyramid" - A servant leadership perspective. Journal of Leadership, Accountability and Ethics, 10(3), p. 98.

Jeucken, M. - Bouma, J. J. (2017): The changing environment of banks. In: Sustainable Banking. London: Routledge, p. 24-38.

Hall, J. K. -Daneke, G. A. -Lenox, M. J. (2010): Sustainable development and entrepreneurship: Past contributions and future directions. Journal of Business Venturing, 25(5), p. 439-448.

Hammill, A. - Matthew, R. - McCarter, E. (2008): Microfinance and climate change adaptation. IDS bulletin, 39(4), p. 113-122.

Henderson, R. M. (2015): Making the business case for environmental sustainability. Chicago

Horváth, D. - Móricz, P. - Szabó, Z. R. (2018): Üzletimodell-innováció. Vezetéstudomány/Budapest Management Review, 49(6), p. 2-12.

Hughes, N. - Lonie, S. (2007): M-PESA: mobile money for the "unbanked" turning cellphones into 24-hour tellers in Kenya. Innovation: Technology, Governance, Globalization, 2(1-2), p. 63-81.

Jeucken, M. (2010): Sustainable finance and banking: The financial sector and the future of the planet. London: Routledge

Kerényi, Á. (2017): A FinTech-jelenség hatása. Hitelintézeti Szemle / Financial and Economic Review, 16(3), p. $32-50$

KPMG (2017): The Value of Fintech, 2017

Langley, P. (2018): The folds of social finance: Making markets, remaking the social. Environment and Planning A: Economy and Space, $0308518 X 17752682$.

Lee, I. - Shin, Y. J. (2018): Fintech: Ecosystem, business models, investment decisions, and challenges. Business Horizons, 61(1), p. 35-46.

Lélé, S. M. (1991): Sustainable development: a critical review. World Development, 19(6), p. 607-621.

Mas, I. - Morawczynski, O. (2009): Designing mobile money services lessons from M-PESA. innovation: Technology, Governance, Globalization, 4(2), p. 77-91.

Mika, J. - Farkas, A. (2017): On Synergies and Conflicts Between the Sustainable Development Goals (20162030) and Renewable Energy Sources for Education of and by Sustainability. Problems of Education in the 21st Century, 75(2)

Móricz P. (2007): Üzleti modellezés és az internetes üzleti modellek. Vezetéstudomány, 38 (4), p. 14-29.

Morioka, S. N. - Evans, S. - de Carvalho, M. M. (2016): Sustainable business model innovation: exploring evidences in sustainability reporting. Procedia CIRP, 40, p. 659-667.

Neven, D. - Droge, C. L. M. (2001): A diamond for the poor? Assessing Porter's Diamond Model for the analysis of agro-food clusters in the developing 
countries. In: Proceedings of the 11th Annual World Food and Agribusiness Forum and Symposium, p. 25-28.

Osterwalder, A. - Pigneur, Y. (2010): Business Model Generation: A Handbook for Visionaries, Game Changers, and Challengers. Chichester: Wiley

Perrini, F. - Tencati, A. (2006): Sustainability and stakeholder management: the need for new corporate performance evaluation and reporting systems. Business Strategy and the Environment, 15(5), p. 296-308.

Pintér, É.-Deutsch, N. - Ottmár, Z. (2006): New direction line of Sustainable development and marketing in green banking.

Porter, M. E. - Kramer, M. R. (2011): Creating shared value. Harvard Business Review, 89(1/2), p. 62-77.

Schaltegger, S. - Lüdeke-Freund, F. - Hansen, E. G. (2012): Business cases for sustainability: the role of business model innovation for corporate sustainability. International Journal of Innovation and Sustainable Development, 6(2), p. 95-119.

Schueffel, P. (2016): Taming the Beast: A Scientific Definition of Fintech. Journal of Innovation Management, 4(4), 32.

Schumpeter, J. A. (1934): The theory of economic development: An inquiry into profits, capital, credit, interest, and the business cycle (Vol. 55). Transaction Publishers.

Simon Cornée - Ariane Szafarz (2013): Vive la Di érence: Social Banks and Reciprocity in the Credit Market. Journal of Business Ethics, Springer Verlag, 2013, 125 (3), p. 361-380.

Sinkovics, N. - Sinkovics, R. R. - Yamin, M. (2014): The role of social value creation in business model formulation at the bottom of the pyramid-implications for MNEs? International Business Review, 23(4), p. 692-707.

Strong, S. (2012): Strong, Straightforward and Sustainable Banking. Global Alliance for Banking on Values. http://www.gabv.org/, downloaded: March 23, 2018

Tate, W. L. - Bals, L. (2016): Achieving shared triple bottom line (TBL) value creation: toward a social resource-based view (SRBV) of the firm. Journal of Business Ethics, 1-24.

Tulchin, D. (2003): Microfinance's double bottom line. MicroCapital Institute, Boston, www. micro capital. org [6.12. 2017].

Tsai, M. S. - Tsai, M. C. - Chang, C. C. (2013): The direct and indirect factors on affecting organizational sustainability. Journal of Management and Sustainability, 3(4), p. 67.

United Nations Environmental Programme Finance Initiative (2016): UNEP FI Guide to Banking \& Sustainability. UNEP Finance Initiative Switzerland

Van den Bergh, J. C. (2007): Evolutionary thinking in environmental economics. Journal of Evolutionary Economics, 17(5), p. 521-549.

Varga, D. (2017): Fintech, the new era of financial services. Vezetéstudomány/Budapest Management Review, 48(11), p. 22-32.

World Bank Environmental and Social Framework (2016): World Bank, Washington, DC

Yip, A. W. - Bocken, N. M. (2018): Sustainable business model archetypes for the banking industry. Journal of Cleaner Production, 174, p. 150-169.

Yunus, M. - Moingeon, B. - Lehmann-Ortega, L. (2010): Building social business models: lessons from the Grameen experience. Long Range Planning, 43(2-3), p. 308-325.

Zilahy, Gy. (2016): Sustainable Business Models - What Do Management Theories Say? Vezetéstudomány/ Budapest Management Review, 47(10), p. 62-72.

Zilahy, Gy. - Széchy, A. (2012): A vállalati környezeti innovációs tevékenység háttere - elméleti áttekintés. In: Fenntartható fejlődés, élhető régió, élhető települési táj 2. Budapesti Corvinus Egyetem, Budapest, p. 91-111. 